\title{
6. Talking Sanguma: The Social Process of Discernment of Evil in Two Sepik Societies
}

\author{
Patrick F. Gesch
}

As with so many others, I was shocked to see the front page photo and read the newspaper article of the Post-Courier, 7 February 2013, captioned 'Burnt Alive'. We all read:

A tragic and brutal sorcery-related murder took place in full view of hundreds of onlookers in a Mount Hagen City suburb in Western Highlands Province yesterday morning. The relatives of a six-year-old boy doused petrol on a woman whom they had suspected of killing the boy with sorcery and burnt her alive ... The victim, who was from Enga Province, was suspected of killing the six-year-old boy through sorcery after he died at the Mount Hagen general hospital on Tuesday. (Wama 2013)

We presume this is a case of highlands sanguma, and the story was followed up by many further reports of sanguma and calls from all over the world to stop this kind of action from occurring. This was murder; but it was promoted by the bystanders because they saw the burned woman as an evil sanguma killer. Does there need to be a special law for sanguma, or was parliament correct in repealing the Sorcery Act 1971 about this time?

Sanguma is a term used widely in Papua New Guinea, and it appears that the term is called upon today more frequently than ever before. The word describes a practice of sorcery or witchcraft, as well as a person or group (college) who perform the practice. I wish to describe sanguma as it has been explained to me in East Sepik Province, which is contiguous with the highlands provinces, but a separate cultural zone ranging from the dominant Sepik River over the densely populated mountains to the coast. The Tok Pisin word sanguma is used in the Sepik and the highlands, and in other provinces of Papua New Guinea as well. There was an attempt to make the Sorcery Act 1971 cover all of these things, but it is a matter of killing by religious instrumentation and I suspect there are as many religions as languages in Papua New Guinea, and the many languages and religions are very different from each other. The stories of how sanguma functions are very much differentiated from each other but share a hold on the religious mysterium tremendum et fascinosum ('might awesome mystery') of Rudolf Otto (1979). There seem to me some aspects of the Sepik accounts which 
clarify how sanguma functions in community reactions, and it is possible that some references to this term can be explained and even accepted by the outside world. An attempt to make a single sorcery law to cover all of Papua New Guinea would be presumptuous.

The term sanguma for East Sepik seems to me to be a statement of a religious nature. When it is invoked, it is a statement that says, 'There are issues of lifeand-death seriousness behind this event. There are powers at work here which are not obvious, discontinuous from what can be observed and which need to be searched out for their meaning for villagers.' My impression is that 'Sanguma!' as a call identifying an event means that a process of social discernment must follow, and in that discernment all the powers of society will be invoked, for the continuance of life for an individual as a social being is at stake.

Even though East Sepik does not rank as a highly reported area for sanguma stories in the national newspapers, ${ }^{1}$ it is a matter of daily concern in most areas. The newspaper article quoted above includes the term 'murder' as a suitable description of the brutality that was witnessed. Although village people in East Sepik sometimes express themselves as sympathetic with highlands procedures, they can distinguish their own sanguma cases from murders. Without doubt, Sepik sanguma has a life-and-death seriousness about it and Sepik villagers think sanguma operators should be identified and killed as one way of eliminating them from the community. However, I believe that the seriousness of Sepik sanguma occurs as a discernment process - divination - without doubting the emphasis on the killing and the danger of sanguma from the village viewpoint (Gesch 1979). When the meaning of a person's sickness is given as that of a wholly useless and offending character, it sets in train a bad feeling that worries a villager to death.

The notion of discernment is that signs are posited or discovered and, from the social context, given a certain mindset; meaning is read from these signs in ways that can be full of bitter consequences. Without wanting to trivialise the matter, discernment can be compared to my mother's habit of reading teacup leaves. She would keep some leaves in the bottom of her cup and interpret pictures from the shapes visible. Then from her mindset and social context she would identify a course of action to follow. Continually, there is a call in the Sepik for identifying signs in cases of illness and death. Today it is possible to identify a murder as a clearly identified killing by another person, ${ }^{2}$ or to identify a death by old age,

\footnotetext{
1 See Table 2, Gender and location of 156 accused and punished sorcerers reported by the media (20002006), in Zocca (2010:199). This information is drawn from Zocca and Urame (2008:74-91). East Sepik Province is not mentioned among the 156 reports, although two East Sepik Province victims appear in the original table. 2 It is still well remembered in Yamuk that around 1998 an ex-Defence man from the village took a gun and shot and killed a thief who stole money from a visiting carving buyer. No one called for sanguma talk in that case.
} 
or an accidental killing, but someone might raise the sanguma possibility, even in such cases. This appears to be a lightening of the dictum that 'nobody dies a death from natural causes in Papua New Guinea'. ${ }^{3}$

In this chapter, I will discuss the sanguma discernment process from two localities in East Sepik Province that are familiar to me after many years in each place: East Yangoru (Negrie parish in particular) and Yamuk village in Pagwi District. ${ }^{4}$ Each locality uses a discernment process to deal with sanguma and the ways of one village shed light on the ways of the other within the unified context of East Sepik. I will first illustrate what is meant by discernment in sorcery and witchcraft. From the discernment viewpoint, there is not a great difference to be observed between sorcery and witchcraft.

Sorcery is the main instrument of religious aggression in Yangoru. It consists of taking leavings of a person and sending them to a remotely located person with learned magical skills. The discernment process for this begins when a person gets sick in a troublesome way (the severity, suddenness, extended duration or features of the sickness) such that there seems to be a sign involved. Sanguma is specifically identified in Yangoru for certain kinds of victims, which I would render briefly as 'bush hysteria' for love-confounded young people. In the Yamuk area, sanguma is the ready recourse for identifying all kinds of troublesome sickness and deaths, and many such evils can become a subject of sanguma. I could not (these days) find much about how to learn to become a sanguma practitioner, but the myth of how it is done on someone is an essential part of village understanding.

It is not my wish to elide Yangoru with Yamuk. Both belong to the Ndu language family, which covers most of the $350,000^{5}$ people of East Sepik Province. Speakers of both places recognise familiarities in the languages, but do not mutually comprehend each other. The East Yangoru village, Kiniambu, from which some of my experience is taken, is only 25 kilometres from Yamuk and there is some market exchange between the places. Yangoru shares the style of the mountain village culture made famous by Margaret Mead for the Arapesh language (Mead 1970). Although there are four electorates in Yangoru-Saussia, I will use Yangoru here as if it were a single entity, meaning East Yangoru (largely co-extensive with the Negrie parish area), where villages are closely contiguous.

\footnotetext{
3 Compare Mantovani (1998:104) further quoted in Zocca and Urame (2008:39).

4 I spent 10 years (1973-1983) in a parish and research appointment in Negrie parish, Yangoru, and since then have been continually in contact with Negrie neighbours in Madang and by return visits to Negrie. My association with Yamuk began in 1984, following contacts in Madang, and in returning for research periods and church building over the years. I confess that it took me 19 years to do something with the 54 sheets of corrugated iron that the parish priest had put in the village to get them turned into a church.

5 The population of East Sepik Province is 343,181, as reported on the National Research Institute website, www.nri.org.pg/research_divisions/cross_divisional_projects/11\%20East\%20Sepik\%20Province.pdf, viewed $26 / 3 / 2014$.
} 
Yamuk is from the Sawos language area, the bush just off the Sepik River, and the villagers identify closely with the cultural world of Gaikorobi (Schindlbeck 1980). Since both places have recourse to a discernment process for sanguma, their practices shed much light on what is meant by sanguma as a word for religious aggression in East Sepik Province. I use two sets of examples from tolerably related areas to explain the discernment process.

\section{The discernment process}

\section{How sorcery discernment works in Yangoru}

I was beginning a Catholic mass in Kiniambu during one visit in 1977. A call came from the village nearby, and all the men immediately stood up, left the church and went down to the village, where they joined in discussions ranging over two full days. A senior member of the community had been taken with a sudden severe illness, in which it seemed he was about to die. There was a discussion during the two days of who might have sufficient hatred in his heart to be trying to kill the big man. Typically for Yangoru, the discussion would go by a procedure of identifying conflicts that the sick man was involved in, as identified by his supporters and family, and putting a coconut leaf rib (nok) into the stripped back of a sago palm leaf (pangal). A number of these sticks are put into a standing position, until those involved in the identified disputes come forward with counter arguments and remove a stick to indicate that the dispute was removed. The procedure continues until a consensus is formed about the sticks that remain standing as witness to lasting disputes with the sick man. In the Kiniambu case, a son-in-law was identified as having a dispute with the sick man, and admitted having taken leavings from a fish that the sick man had been eating, so that sorcery could be worked on this material. This is a way of doing sorcery identified as tak in Tok Ples (vernacular language), or poison in Tok Pisin (Melanesian pidgin). It takes place as a discernment process: who has enough hatred in his heart to want to make the sick man die? It is to be noted that an expert who can cause this magic is presumed in the action, but this expert is nowhere identified or sought out, because he is expected to be in some area remote from the discussion.

To make poison work, six agents are required and all of them taken together make for a juggling act in the discernment process. We take the sick person first, and second the person with hatred in his or her heart, who is the real killer in the process and who must find the cast-off materials to use in the magic. However, the community discussion is called when the sickness shows signs of being something beyond ordinary daily experience. Fourthly, a big 
man of the village has to weigh the consensus. Once a big man of the village said to me, 'Nobody dies in this village unless I say so. I am the only one who kills by poison in this village'. When I questioned him whether this might not be a dangerous acknowledgement, he said that of course he means he passes on a person's leavings together with 100 kina or shell money to the pertinent messenger to get the magic done in some other, remote village. It is the big man's job to form the consensus on the need for the killing. The messenger has a traditional name - mowintuo. He delivers the message, the materials and the valuables to a real magic-working person called a yehwontuo. Finally, this man sits in his house with a fire and a bowl of lime and brings religious knowledge to bear on the parcel of leavings, which is exposed to the magic. The victim gets sick and can be relieved or finally disposed of depending on the action of the yehwontuo. The magic man is moved by payments that come from the original community. This social discernment would not differ greatly for sorcery or for witchcraft.

\section{Is sanguma real?}

The above description emphasises the discernment aspect of the sorcery or sanguma process. Advantages in doing this are that it provides an alternative answer to the question, 'Is sanguma real?' It is real inasmuch as the sick person is struggling to clear his name in the village and to say that he should not be cast off to die at the wish of the people. It does not need to be real in the sense of using objects of aggression such as long sharp needles, torture or chemical poisons. Also, it is part of the argument: Will the death penalty solve sanguma? Whom could you convict in such a scenario since the actual practitioner of religious powers is remote and unidentified? The real killers are the ones with hatred or condemnation in their hearts, the purveyors of personal materials and the community sitting in judgement. Perhaps any death penalty should apply to the purveyors and the community, but we are dealing with a traditional justice system, and the sick person or the dead person or the ones whose houses have burned down are the offending people in the view of the sanguma discernment and discussion. ${ }^{6}$

Is sanguma a nonsense, non-scientific belief that might work just because people believe in it? Clearly a belief in the sanguma discussion process is something that is hard to shake loose when the whole community is forming a consensus about a person's value as a community member. To say that something is 'merely belief' seems miserably short as self-reflective knowledge. Belief can build a

6 It is not easy to be sympathetic with this viewpoint from a European perspective. For example, at the seashore I was reassured that I would not be taken by a shark (or crocodile): 'sapos i no gat rong long skin bilong $y u^{\prime}$. This means that if I do get taken, it is an indication that I am guilty of some village wrong. This is adding insult to injury with a vengeance. 
tall building in a way that a hammer cannot. At the same time, this description supports the view that the older members of the community pass judgements on sanguma, but the young men take it into their own hands to work violence on suspects. This is just murder on the part of the vicious young men, something extra to the discernment work, and not part of the question: What is sanguma? It must be observed again, that in East Sepik the sorcerer or the sanguma person is not deeply involved in the discernment process, although he is completely necessary to the ideology that guides the discussion. Sanguma people and sorcerers are killed if villagers get the chance, and the killings are applauded, but the real focus is on the person with hatred or condemnation in his heart sufficient to want someone dead by direct religious means. The person who initiates any particular sanguma magic will suffer retaliation only when the family initiates revenge magic.

There are two bridging questions to get from discernment to highlands sanguma cases. One, does the sanguma in East Sepik ever make his own decision about killing or letting live? Two, does it help to kill someone identified as sanguma? Brief answers are: Yes, informants tell me the sanguma can take it on himself to presume the consensus of the community and do his work directly. Second, the college of sanguma is very important, and it would be a great risk to kill a sanguma because the group could retaliate on either yourself or any family member.

Before enlarging on these answers, I will describe Yamuk sanguma and Yangoru sanguma in more detail.

\section{Yamuk sanguma}

\section{How the sanguma work in Yamuk}

The power of sanguma in Yamuk belongs to the community. The sanguma person can secretly go to the haus tambaran (spirit house, a large and elegant construction dominating a village of the East Sepik) and address the garamut slit drum. This garamut is a large, wooden log carved with a trough down the middle. When struck with a solid stick it is used for solemn announcements throughout the village and for kilometres beyond. This drum has an ongoing intergenerational spirit name and many spears used to go into the middle trough at the time of war with an enemy or when men are trying to shoot and kill bush pigs. When a pig is killed, the men bring the blood back to the haus tambaran and sprinkle it in the house, over the garamuts and the beds where men sit to talk. The garamut thus gathers a historical memory of power and the living tradition of the village. This general collection of memory and things 
is called kipnda, the strategic memory of the village. The sanguma can draw on this history of spells, prayers and pig offerings to gain power for his own purposes. He does so by using words at this locality. This is the sifuo kundi, the powerful magical spell. In this sense some men say that everything in the haus tambaran is sanguma - the house posts, the ground, the drums, beds, stools and whatever is hanging from the roof. These things are witnesses to the power of historical activities and indicate the presence of spirits that may go around the village fires at night and gather the opinions and judgements of those with criticisms to make. ('Samting bilong graun i save kirap na raun long paia bilong ol man long nait.')

When someone is to die by the hand of sanguma, there will be signs at night: you might think you see some men in the shadows of the night; flying foxes might surprise you by forming a chain; or a certain frog or bird will call out as the mark of the sanguma. These shadows or signs might surround the house where a sick man lies. In the recent case of John Kangra, ${ }^{7}$ he had a fever on and off for a whole week, and it seemed there were shadowy figures of men around the house and even inside the house watching the sick man on his bed in the presence of his family.

After John died, there was a quick examination in the nearby haus tambaran. Did anyone have disputes with him about the bush or ownership of land, the use of sago trees or in relationships with women? Some signs of this would be expected to appear. In this case a woven coconut leaf was thrown into the family house, and a coconut shell full of Bougainvillea flowers was found outside the house. This indicated to the family that a longstanding land dispute was at issue and this dispute was connected to a fellow villager. They could not say that the man with the dispute was a sanguma, but he could have hired a sanguma to kill John. Alternatively, it was admitted that the sanguma himself could have simply made the judgement that John should be killed for this longrunning dispute. When it came time to discuss the issue in the haus tambaran after John's death, there was no calling of names. It was not necessary, because the land dispute existed from a long time ago, from the grandfather's time. This death was something the family would have to live with or they would have to retaliate with sanguma.

The explanation given by members of the community was that someone went to a sanguma with some money or a present and said it was about time John suffered or died. After the death the complainant would have had to visit the sanguma again to get his money back as a way of telling the sanguma that he had not really wished the death to take place. If the sanguma himself had not wanted to kill John, he would have tested John's goodwill by asking for a favour

7 I am not using real names of persons but pseudonyms throughout. 
and then advising John to have an urgent discussion with the complainant. A sanguma gains a reputation by people going to him to ask him to make a sick person well, and by accepting money to inflict illness or to remove it. This is the politics of the sanguma discernment process.

The ideology known to everyone in the village is that a Yamuk sanguma works by going with his group to the offending party, such as John. The sanguma are senior men in Yamuk village or men or women from nearby villages. It is possible that they could be identified, and many times people tell me, 'That fellow is definitely a sanguma'. This accusation is of course dismissed by the fellow himself. The sanguma knock the victim out, generally expressed as 'killing' him, and then operate on him by removing some of his internal organs, parts of his major muscles, his penis or other meat. This meat will be kept and dried as a powerful agent of sanguma work. When the sanguma next wants to work, he will scrape this piece of meat with his teeth or breathe his spells over it. The sanguma will revive the man they have 'killed', and ask him if he recognises them. If he does recognise them and what they did, he will be knocked out again and revived until finally he does not know the sanguma who have terminated his life. The victim is then sent away with knowledge of the day and the circumstances under which he will finally die, but with no recognition of the sanguma men who have killed him. In the case of two brothers who had a longstanding dispute about some money, it was reported to me that the victim announced what was going to happen saying, 'I am going now. I will fight with my brother and I will die.'

\section{Cases of sanguma from Yamuk}

The name sanguma is connected with surprising and disturbing evil in the form of sickness or death, or misfortune such as house fires. But it is a word that can be further used for a range of worrisome matters.

At our tertiary institution, we had the sad experience of an apparently healthy village Torembi ${ }^{8}$ student suddenly collapsing and dying on the sports field. After playing 15 minutes of a friendly soccer fixture, he took a five-minute break, and then ran back on to the field. There he collapsed and was pronounced dead at the hospital within an hour. ${ }^{9}$ While the death of the young man is hard to come to terms with, the ready explanation or comment for his death is just as hard to come to terms with. Staff of our tertiary institution remarked, 'Clearly this was a case of sanguma'. If we take a loose idea of a sanguma to be a person with exceptional powers causing death or injury to another person in the context of social dispute, it is hard to see where the evidence of this appears

8 Torembi is a village near Yamuk, three-and-a-half hours walk away, largely sharing the same culture.

9 An Australian medical doctor told me that such sudden deaths of sports players are known in Australia also. 
so obvious to some. Yet most times at morning tea our college staff discuss the well-being of people around us, and lecturers comment that some cases are 'clearly a case of sanguma'.

The word for sanguma in Torembi is kuragua. I once drove a young friend from Torembi downtown in Wewak. He left the car to go about his business, but jumped back in the car within a minute. In front of us was someone I considered to be a gentle old man of Torembi village, occasionally involved in church affairs. The young friend said that he was a well-known sanguma man and he was scared at seeing him. ${ }^{10}$ On another occasion, an old catechist of the church from former times had gained a reputation as a carver of Christian images. He was accused of being a sanguma. At the end of an enclosure for an initiation ceremony, the old man had his wife follow him, and together they limped around the enclosure before the eyes of everyone, as if they were following a trail on the ground, the wife emitting the call of a 'sanguma bird'. The old catechist explained to me that everyone, including his son, was pointing to him as a sanguma but that was obvious nonsense, so he was acting out his supposed evil ways of pursuing victims. Those around me were not convinced; they claimed they had evidence that he had taken money to do his nefarious deeds.

One summer I went to Yamuk village on the hunt for evidence of sanguma in its social context. I kept asking men in the men's house for evidence. The evidence was always fresh and current. For example: 'Last night we were late coming back to the village when we heard someone running through the dense bush. It was not a pig. Don't you think we know the difference between a person running through the bush and a pig running through the bush? This was the sound of some sanguma people.' As we were sitting in the men's house at $11 \mathrm{am}$ that day, a loud cry went up from nearby, 'Willie has collapsed. He is throwing up and they are carrying him to his house.' Men turned to me and said, 'You wanted evidence. There, you have it now.' For the next few hours healing men performed various rituals for Willie, a strong and otherwise healthy adult, married with a family, as we sat in his house. Finally, a one-centimetre-long spear was taken out of what Willie had ejected into a coconut shell, and buried in the bush near the toilet. Willie started to improve in health after that. I was told that I now had all the evidence I could possibly ask for.

At one time I entered a hausman (small open house for men's gatherings) in the village of Yamuk and was surprised to hear two adult men shouting at their father that he was a sanguma and that he had better stop his evil deeds.

10 To have a reputation as a sanguma in Yamuk does not mean that the person is likely to be a social outcast. Of the men in Yamuk who have been identified to me as 'leading sanguma', some were truly strong and effective church leaders in my estimation; others were village councillors. Such people do put in a word of defence for the sanguma process, saying 'Beware of getting rid of sanguma altogether. How do we deal with really bad troublemakers living among us otherwise?' 
The father appeared unmoved by these hostile public recriminations from his family. I was told that the meaning of this was that a sanguma does his work of killing people with the help of fellow sanguma. One gets his colleague to kill the undesirable person, but in retaliation and payment, one of the junior members of the first group will have to die also. So, to be part of a group sheltering a sanguma was to be in a dangerous position - you kill this offending person for me, and then I will have to kill someone from your place or family to repay this.

Below is a collection of examples of the use of sanguma in Yamuk in other contexts.

- A young man of Yamuk was drinking beer with his friends in a Wewak settlement. Three shadowy persons called him below the house and told him to go with them. They appeared hazy but he kept talking with them and later when he asked others about what he had done, they said they had not seen anyone with him. Clearly these had been sanguma men and he was frightened because they were jealous of his success.

- Another young man had great pain in his groin. He was cured by magical spells, according to his friends, but somebody discerned the meaning of this to be that he was initiating a train of sanguma action for his family, and he was in fact the son of John Kangra, mentioned above, who died soon afterwards.

- After drinking alcohol continuously for days, a young villager went into his house and started cutting his own clothing and throwing it outside the house, a sign of going away for a long time. A few hours later he died in a fight after suffering a blow that did not seem lethal proportionate to the force used. These matters were taken as signs of sanguma. Whether the youth had a sufficiently bad reputation to deserve elimination was left to individual judgements.

- An older man was found to have a broken shoulder and neck bones after he died. This was an indication that he had been taken by sanguma, operated on, and then revived to wait his inevitable death.

- There is a set of stories about the playfulness of sanguma, which is one way of insisting that sanguma are powerful people with special spiritual powers. My judgement is that the stories are fables to entertain, but they are told as true accounts. A young man walking with his father was carrying a bundle of firewood. It became too heavy to carry and he had to put it down. Then he realised his father was no longer with him, but appeared to him as a little man coming out of the firewood bundle. Using a special kind of lime powder, sanguma can disappear or reappear in the form of another person. They can make themselves into small creatures, in the manner of one person outdoing another person, or just for a joke. The playfulness in these stories seems 
at odds with the killing or injuring intent of sanguma, but nevertheless demonstrates powers beyond normal human powers.

In all these cases villagers follow an ideology of looking for signs in evil things that they are experiencing and identifying their causes in the religious powers of specially trained, skilled persons. When these powerful people cause harm, this meaning can be uncovered by community discussion looking for a history of past social offences. These sanguma might have objects inside their bodies to assist them in their powers and communication. They do not inherit these things in a biological sense but pick them up during training. Their decisions to act are informed by community discussions among men and women that might go on at firesides anywhere, and then in consultation with their colleagues they take the action of inflicting pain and trouble.

\section{The social discernment of evil in Yamuk}

The process of discernment in Yamuk is a public one, as for the Yangoru procedure. Men are summoned by the garamut drum to gather in the haus tambaran. Speeches are made with the help of three bundles of long tanget leaves. The speaker beats the mouth of the garamut (in other Sepik communities a speaker's chair is used as a table for beating) and sets the scene for the discussion. Anyone can speak in reply, beating the garamut and then laying down the three bundles of tanget leaves one by one as he talks, before gathering them up again to repeat the action. ${ }^{11}$ There is an effort to gather evidence, the history of arguments, points of view and reasons for actions. Sometimes the speeches can become very angry displays of opposition. Comments made about the proceedings show that the men believe that sanguma persons are actually sitting with the other villagers in the haus tambaran, watching the formation of opinion about what has been done, or about the personality of the one who is sick or has already died. The sanguma are also watching for evidence or reports of payments that have gone in any direction.

As was said earlier, it is fairly common for villagers to make a statement like, 'Sengi is a sanguma. He is one of the strongest sanguma in the village.' If you ask such a man, he will say, 'Nonsense. We have no sanguma in our village. If you go to Slai village, yes, there are sanguma there, and many of them are women.' Such charges are common. It is apparently hard to gather a body of feeling in the village that Sengi must surely be a sanguma. People in town settlements say they do not like village life because sanguma are a threat to good living; they would like to see them all removed. Then they will say, 'After you live in the village for some months and you don't do anything wrong, then you will find you

11 My observation is that the beating with the leaves is not very rhythmical, and not used to highlight points so much as a nervous thing to do with the hands. 
can continue to live peacefully at home'. To turn to someone and identify that person as a sanguma has the difficulty already mentioned, of rousing the wrath of the college of sanguma. They work together, coming from nearby villages to form their decisions and do their work at any place, employing mysterious powers of invisibility or of seeing all things. This is the myth of how sanguma persons work in Yamuk and this is the basis of intense feelings of fear, revenge and uncertainty.

When I am pursuing the topic of sanguma, I ask: What is a sanguma? How do they function? What do they want? How do you deal with them? After I have collected a set of narratives like those given above, my research assistant repeatedly comments, 'They are hiding it from you'. While I believe my assistant wants to hear names, dates and cases from village life in order to pursue local politics with other villagers, I think that I am trying to gain clarity on the general nature and structure of sanguma action. What is an answer that would satisfy me?

Before I turn to that discussion let me add the case of Yangoru sanguma as a way of discernment that sheds light on the sanguma concept.

\section{Yangoru sanguma}

Sanguma in Yangoru is termed maientuo (a witch man). The action is related in its function to sorcery, called tak in vernacular and poison in Tok Pisin. ${ }^{12}$ Both these operations are a part of the sickness of any person seriously ill in the village. It was often something of a puzzle to me that I would sit in a church council meeting of a Sunday and hear people say that Christians should denounce the bad old ways and affirm the good traditions of the ancestors. Definitely sanguma and sorcery were part of the bad old ways. Then everyone would rise from the meeting to go home because back in the village there was talk of tok poison going on. The leaders had to be present, and there was no way they could refrain from talking. In village meetings the church leaders would talk about disputes in the village involving a sick person in some way. I understand that there are bad ways of talking about people involved in disputes and better ways. So the Christian leaders' duty was to keep the village discussion running in a good way. But from a certain viewpoint it can be said that talking tok poison is the essence of what sorcery is all about. This is because it is the discernment process where the villagers talk about the offences of an individual, guess at his motives

12 I give the two words from the Yangoru vernacular, maientuo and tak, but they are not shared in the Yamuk vernacular or in other East Sepik language groups. Therefore I have chosen to remain with the Tok Pisin word sanguma, which is somehow understood all over Papua New Guinea. The reason I give the Yangoru vernacular at all is to emphasise that these are separate traditional concepts. 
and his future trajectory and what would be appropriate to chasten such a person. Whoever has indulged in gossip will know the sweetness of character assassination that gets community backup.

It seems there was little attention paid to the witch or sanguma person in Yangoru. Philip Gibbs has given a recent account of witchcraft magic from the nearby and similar Arapesh language group, detailing materials to be used and the people who use them (Gibbs and Wailoni 2009), but this topic rarely surfaced for me when I was asking about sanguma matters in Yangoru. Who commits witchcraft and how? In my first 10 years of exposure to Yangoru, there were few incidents referring to actual known people with special powers of sorcery and none involving those doing witchcraft. One day high school boys came back from Yangoru to Negrie nearby to report that a 200-litre drum was set in the middle of Yangoru, filled with small packages of palm leaves representing sorcery materials wrapped up. The boys found it horrifying. Another time I was in the village shortly after a man had had his house inspected by self-appointed sorcery police, and they had found a small package of waste materials that could be used in sorcery. This man admitted that he had been uncovered and was penitent, but said that he had been keeping this thing just in case it was needed against the person being stalked. On another occasion I was introduced to a 45-year-old, cleanly shaven man sitting with the men at a hamlet in the village. This was John $\mathrm{M}$ and he had been a sorcerer living alone on a remote mountain ridge, making money from those who wanted him to perform magic to harm people. He also received money for removing the spells. John said he did not want to be a sorcerer anymore and had turned to the church. The community had accepted him back. ${ }^{13}$ Apart from these three incidents demonstrating real sorcery, it was said that the sorcerers were always men from distant communities, faceless and remote, not liable to be tortured, interrogated or murdered as sanguma.

The appearance of sorcery symptoms in Yangoru seems to me a form of hysteria or catatonia, as Sigmund Freud used the expression. ${ }^{14}$ One afternoon a schoolboy about 15 years old was brought to me. He was helplessly, unceasingly crying. He had previously been identified as having had sexual relations with a young girl in our dormitory area at the school. My guess is that that afternoon, while collecting firewood, he had had a terrifying encounter with a small group of men in the bush to remind him of this, and was reduced to hysteria. He was helped by an old man in a nearby community who had skills in this area. On another occasion, a 25-year-old school teacher with a public, troubled relationship with

13 Recent news is that John has returned to his old way of life. The performance of magic was too much a part of his personality to give up, and he needed the money.

14 This is not to be taken as a psychiatric diagnosis, but as a literary reference. The articles of Micale (1993), and Owens and Dein (2006) warn us of historical difficulties with these terms, which are not to be interpreted here in a clinical way. 
her presumed partner, walked back to our school and sat in her house. She was motionless, and I personally witnessed a sewing needle stabbed into her arm without her flinching. On a further occasion, a strong young man described how he had met men in the bush who had apparently worked some spell on him. After that he wanted to return every day to see them, even though he made signs to indicate that in five days he must die. The elements of these stories are repeated in further cases. It seems to me that they refer to young people who are in a confused state with regard to sexual relationships, and sanguma becomes a form of planned social terror to give them a severe warning.

There remains to be uncovered or guessed at the story of who the sanguma person is in relation to the village or the afflicted person: how did this person get his or her powers, how did the act of sanguma or sorcery take place, and how can the victim be helped to shake off the effects of sanguma? I doubt that this aetiological explanation is necessary for my understanding of what is going on.

What is 'understanding sanguma' in this situation? What mindset can I employ to be able to follow the conversation and anticipate the turns that the story takes? Even if the story is wickedly evil or nonsense for the lack of verifiable evidence from some viewpoint, the story continues, and whole communities continue to use this idiom for sickness and social disruption. What comes closest to an understanding for me?

\section{The problem of explanation of sanguma for two mindsets}

At the death of our university student, I was interested in a set of biological connections that could be seen as causative on a level leading to death of the bodily system. Some community and family members related the death to a presumed social dispute, and proceeded to uncover who had a sufficient dispute with the student's family as to set in motion special powers that would cause his death. A pathologist was hired from Lae and a post-mortem conducted. The pathologist found 80 per cent occlusion of the arteries. The student was known to have been drinking distilled alcohol continuously for three days before the game. But this was not enough and some statements I heard clearly identified the person likely to have employed sanguma in this case. Was there evidence to satisfy me about this extra step? Yes, there was circumstantial evidence to look for - a person employing sanguma has to give a payment to make the bodily affliction take place by religious powers. Further payments might be made to make the sickness worse, or to provoke a response from the sick person and his family, or to end the life of the person. The sanguma associate with other 
sanguma people in a group. The members of this group accept money to do their magic. When word of their accepting money gets out to the public, people can begin to identify sanguma with hard evidence.

\section{Talking about sanguma}

The problem is: how do we talk about sanguma usefully in Papua New Guinea? Sanguma is one of many Tok Pisin words that are polyvalent, meaning something different in the different cultures of the country; other examples being kandere and other family connections like brata, papa, mama, bikpela. These words need to be defined on the basis of cultural expectations and performance, not just as static relationships. Not only do we know from recent Melanesian Institute publications that sanguma means something different in the highlands and on the coast (see, for example, Bartle 2005; Gabutu 2012; Kuman 2011; Schwarz 2011; Zocca 2009; Zocca and Urame 2008), but there is an obvious cultural divide between Papua New Guinean villagers and overseas missionaries or educators about what the word means. The simple answer is to say that sanguma is an application of remotely working mechanics; or nonsense belief; or worse, that it is sin or causes sin and not a fit topic of conversation for reasonable people. But if we presume all the people who take part in the sanguma conversation are reasonable people, then what kind of explanation is fitting and reliable for this topic? At first my answer to this might seem to reveal my original, Australiantype prejudices. An answer for me needs to cover all the evidence and be attuned to what the evidence is; it needs to predict the behaviour of participants; it needs to be repeatable in different places and times and with different people; and it needs to be a heuristic model able to accommodate future evidence. In other words, it needs to be scientific. Social science depends on social evidence and it is admitted on all sides that evidence has to be found which is convincing to the cultural group and their interlocutors. Let me now flesh out a mindset that is useful in discussing sanguma from two different viewpoints - an Australiantype mentality and a village one — where a mindset refers to an enquiring attitude looking for specific types of evidence and being satisfied with certain types of explanation.

What is sanguma in Yangoru? What is sanguma in Yamuk? They are both signs of social disruption, disputes and even mortal hatred between community members. My earlier question, can a sanguma initiate a killing by himself, does not make much sense in Yangoru, where the sanguma is not present to deal with on this matter, or to receive instructions from community discussion. But the question is more pertinent in Yamuk, where sanguma actions are initiated by a person with a serious concern going to a 'known' sanguma person and talking about what upsets him, doing so with the giving of a gift. One then leaves the 
matter for the sanguma person to discuss with his fellow sanguma. They might decide to afflict the person who gives the offence. As noted earlier, if the person with the complaint sees that the offender gets sick, or even dies, then he acts to hide the trail of evidence leading to himself. If his money has caused the death of someone, then he should go back to the sanguma and get his money back so that the evidence is removed. After that he can give the sanguma twice the amount to express his happiness at the death that has taken place. Not to remove his complaint money would invite retaliation from the sanguma college, who would want to exact a balancing death for the one that took place. In this case, a member of the community is initiating the work of the sanguma, but it is left to the sanguma college to make a judgement and to take action.

To use the term sanguma is thus to summon the community to investigate and reveal what is going wrong in social relationships, or to find out whether a person can be healed, why another person has died, why these 10 houses have burned to the ground or why the crocodiles have led to the disappearance of community members. People are looking for signs, they want to know what the signs mean, and there is a considerable level of fear about being killed by mysterious religious powers in the hands of some men or women. In Yamuk, even the sanguma are involved in the process of social discernment in the community.

\section{The way forward}

In the course of writing this chapter, examples of sanguma have come to light in the national newspapers from the broader Momase area, the north coast of Papua New Guinea. Madang, long known as the beautiful province, the peaceful province, has now produced a series of anti-sanguma movements, which entail mass murders (Mark 2014a). The Black Jesus movement of Steven Tari involved sexual rituals and cannibalism, leading to the brutal killing of Tari by his own villagers (Marks 2013; Matbob 2010). ${ }^{15}$ In the western end of the province at Tangu, an anti-sanguma movement led to many killings (Gumar 2012). More recently, the people in the mountains above Gusap, in the Nahu Rawa local level government area, have concluded an initiation hausman with the pursuit and killing of sanguma (Mark 2014b). There are said to be about 300 sanguma waiting for identification. An eyewitness says that, at the time of writing, the killing of sanguma or hausman persons has become vicious and brutal with many being slaughtered on both sides, and dead bodies have become unremarkable, as decapitated people die like animals in the bush.

15 The term sanguma is not used of this movement. The Black Jesus movement has some derivations from the earlier cargo cult movement of Yali that Peter Lawrence (1964) wrote about. But these days Black Jesus belongs to the context of sinister village movements and monstrous killing. 
Considering situations like this — socially complex movements of murderous and monstrous seriousness, akin to tribal fighting — the idea of sanguma and how to tackle the question on a national, legal level becomes very much moot. Is there anything at all in common between Madang sanguma, and that of East Sepik or of Simbu and Southern Highlands provinces?

In Madang, the community longs for the government to take the situation seriously. A mediation team came and went with no follow-up. Everyone wants identified sanguma people to be eliminated from the communities. Can this be done with a discernment process, or by a trial by torture seeking confessions, or by simple 'surrender'16 ceremonies? The polymorphism of sanguma advises against any uniform national policy for the problem. Local communities require follow-up from the government and police when things start getting out of hand. Given the right understanding of the various sanguma processes, I would have to come down on the side of education and progressive experience to work against the sanguma religious reaction. If you cannot tolerate the religious dimension in life, then it will be difficult to allow any traditional interpretation to hold sway. But villagers recognise grudgingly that penicillin, as well as magical spells, is very good for horrible sores. Education does get things done in the long term even though it is as irrelevant as government in the short-term. The short-term answer is reconciliation and retributive justice, as in Bougainville. The long-term answer to sanguma is better health services, better education and effective government.

\section{References}

Bartle, N. 2005. Death, Witchcraft and the Spirit World in the Highlands of Papua New Guinea: Developing a Contextual Theology in Melanesia. Point No. 29. Goroka: Melanesian Institute.

Gabutu, G. 2012. Sorcery and Magic according to the Motu, Koita and Koiari Peoples of Port Moresby. Catalyst 42(2):146-59.

Gesch, P. 1979. Magic as a Process of Social Discernment. In N. Habel (ed.) Powers, Plumes and Piglets. Adelaide: AASR, 137-48.

\footnotetext{
16 Surrender, given sometimes in Tok Pisin as salenda, appears frequently in the newspapers when youths are pictured before homemade guns lying on the ground and implements for distilling alcohol. Communities clean themselves up regularly. Some of these troublesome implements are removed, replacements are found, but in some sections of the community progress is made, while in others a surrender is just part of the tension of modern life. A Gusap sanguma who hands over his implements of herbs and tree barks with a confession will be allowed to go free. Whoever runs away will be pursued and killed.
} 
Talking it Through

Gibbs, P. and J.J. Wailoni 2009. Sorcery and a Christian Response in the East Sepik. In F. Zocca (ed.) Sanguma in Paradise: Sorcery, Witchcraft and Christianity in Papua New Guinea. Point No. 33. Goroka: Melanesian Institute, 55-96.

Gumar, P. 2012. Eradicating Sorcery Backfires on Villagers. The National, 13 July, p. 65 .

Kuman, G. 2011. Sorcery, Witchcraft and Development in Papua New Guinea. Catalyst 41(1):19-37.

Lawrence, P. 1964. Road Belong Cargo. Melbourne: Melbourne University Press.

Mantovani 1998. Challenges of the Bible to Christian Life in PNG Today. Catalyst 28(2):102-16.

Mark, D. 2014a. Community Living in Fear. The National, 27 March.

Mark, D. 2014b. Mass Arrests. The National, 22 April, p. 1.

Marks, K. 2013. Hacked, Slashed and Castrated: How 'Cannibal' Cult Leader 'Black Jesus' Steven Tari Met His Death. The Independent, 2 September. www. independent.co.uk/news/world/australasia/hacked-slashed-and-castratedhow-cannibal-cult-leader-black-jesus-steven-tari-met-his-death-8795240. html, viewed 13/5/2014.

Matbob, P. 2010. Black Jesus Behind Bars; but Says He Did Nothing Wrong. Islands Business December 2010, p. 29.

Mead, M. 1970 [1938]. The Mountain Arapesh. 5 volumes. Garden City, New York: Natural History Press.

Micale, M.S. 1993. On the 'Disappearance' of Hysteria: A Study in the Clinical Deconstruction of a Diagnosis. Isis 84(3):496-526. http://www.jstor.org/ stable/235644, viewed 24/5/2013.

Otto, R. 1979 [1917]. The Idea of the Holy. London: Oxford University Press.

Owens, C. and S. Dein 2006. Conversion Disorder: The Modern Hysteria. Advances in Psychiatric Treatment 12:152-57. http://apt.rcpsych.org/ content/12/2/152.full, viewed 24/4/2013.

Schindlbeck, M. 1980. Sago bei den Sawos (Mittelsepik, Papua New Guinea). Untersuchungen über die Bedeutung von Sago in Wirtschaft, Sozialordnung und Religion. Basel: Ethnologisches Seminar der Universität und Museum für Völkerkunde. 
Schwarz, N. 2011. Thinking Critically about Sorcery and Witchcraft: A Handbook for Christians in Papua New Guinea. Occasional Paper No. 14. Goroka: Melanesian Institute.

Wama, R. 2013. Burnt Alive! Post-Courier, 7 February, p. 1.

Zocca, F. (ed.) 2009. Sanguma in Paradise: Sorcery, Witchcraft and Christianity in Papua New Guinea. Point No. 33. Goroka: Melanesian Institute.

Zocca, F. 2010. Gender and Accusations of Malevolent Sorcery and Witchcraft in Papua New Guinea. Catalyst 40(2):192-206.

Zocca, F. and J. Urame (eds.) 2008. Sorcery, Witchcraft and Christianity in Melanesia. Melanesian Mission Studies No. 5. Goroka: Melanesian Institute. 
This text is taken from Talking it Through: Responses to Sorcery and Witchcraft Beliefs and Practices in Melanesia, edited by Miranda Forsyth and Richard Eves, published 2015 by ANU Press, The Australian National University, Canberra, Australia. 